\title{
Configuration of Primary and Recurrent Aggressive Fibromatosis on Contrast-Enhanced MRI with an Evaluation of Potential Risk Factors for Recurrences in MRI Follow-Up
}

\author{
Konfiguration primärer und rezidivierender aggressiver \\ Fibromatosen in der kontrastmittelgestützten MRT mit \\ einer Evaluation potenzieller Risikofaktoren für Rezidive \\ in MRT-Verlaufskontrollen
}

Authors

Sam Sedaghat ${ }^{1}$, Alexey Surov ${ }^{2}$, Sebastian Krohn ${ }^{3}$, Maya Sedaghat ${ }^{1}$, Benjamin Reichardt ${ }^{4}$, Volkmar Nicolas ${ }^{1}$

\section{Affiliations}

1 Institute of Diagnostic and Interventional Radiology and Nuclear Medicine, BG-University-Hospital Bergmannsheil, Bochum, Germany

2 Department of Diagnostic and Interventional Radiology, University-Hospital Leipzig, Germany

3 Department of Prosthodontics, University Medical Center Göttingen, Germany

4 Institute for Diagnostic and Interventional Radiology, University-Hospital Essen, Germany

Key words

aggressive fibromatosis, configuration, MRI, risk factors, recurrence, post-treatment

received 09.07.2019

accepted 01.10.2019

Bibliography

DOI https://doi.org/10.1055/a-1022-4546

Published online: 17.10.2019

Fortschr Röntgenstr 2020; 192: 448-457

(c) Georg Thieme Verlag KG, Stuttgart · New York ISSN 1438-9029

Correspondence

Dr. Sam Sedaghat

Institute of Diagnostic and Interventional Radiology and

Nuclear Medicine, Berufsgenossenschaftliches

Universitätsklinikum Bergmannsheil,

Bürkle-de-la-Camp-Platz 1, 44789 Bochum, Germany

Tel.: ++49/01639639740

samsedaghat1@gmail.com

\section{ZUSAMMENFASSUNG}

Zielsetzung Analyse der Erscheinung primärer und rezidivierender aggressiver Fibromatosen (AF) in der MRT mit Fokus auf Tumorkonfiguration und Evaluation potenzieller Risikofaktoren für Rezidive in MRT-Verlaufskontrollen.
Methode Von 79 Patienten mit histologisch gesicherter Diagnose „aggressive Fibromatose“ unterzogen sich zwischen 2008 und 201839 Patienten mindestens 4 1,5 T-MRT-Verlaufskontrollen nach Resektion der Primarien. Die Primärund Rezidivtumoren wurden radiografisch auf Konfiguration, Begrenzung und Ausdehnung in der MRT untersucht. Epidemiologische Daten und lokoregionäre Weichgewebsveränderungen (subkutane Ödeme, Muskelödeme und postoperative Serome) wurden eingeschlossen.

Ergebnisse Das mittlere Alter der Patienten betrug $39 \pm$ 2,6 Jahre. Primäre und rezidivierende AF traten bevorzugt am Oberschenkel auf. Primäre AF waren signifikant häufig faszikulär konfiguriert ( $p=0,001-0,01)$ und wiesen eine inhomogene und kräftige Kontrastmittelaufnahme auf. Bei $21 \%$ der Patienten $(n=8)$ fanden sich im Verlauf Tumorrezidive. Die Tumorrezidive waren meist ebenfalls faszikulär konfiguriert und wiesen ein homogenes/inhomogenes und kräftiges Kontrastmittelenhancement auf. Dennoch können Rezidive aggressiver Fibromatosen auch nodulär, polyzyklisch, oval oder streifig konfiguriert sein. Rezidive aggressiver Fibromatosen traten signifikant häufig in den ersten 9 postoperativen Monaten $(p=0,009)$ und insbesondere bei Patienten bis 25 Jahre auf (relatives Risiko (RR) =6,1; 95\%-KI: 1,8-20,9; $\mathrm{p}=0$ 0,004). AF-Rezidive waren im Vergleich signifikant kleiner als Primärtumoren $(p=0,001)$. Posttherapeutische subkutane und muskuläre Ödeme zeigten sich bei $77 \%$ bzw. $56 \%$ der Patienten. Patienten, die nach Primärtumorresektion Muskelödeme aufwiesen, zeigten ein signifikant erhöhtes Risiko für Rezidive $(R R=1,8 ; 95 \%-K I: 1,16-2,8 ; p=0,0096)$. Es ergab sich kein signifikanter Unterschied zwischen vollständiger und inkompletter Resektion in Bezug auf die Rezidivrate.

Schlussfolgerung Primäre und rezidivierende aggressive Fibromatosen weisen meist eine faszikuläre Konfiguration auf. Dennoch können die Tumoren auch oval, nodulär, streifig oder polyzyklisch konfiguriert sein. Ein erhöhtes Risiko besteht für Patienten bis 25 Jahre, innerhalb der ersten 9 postoperativen Monate und bei Vorhandensein von Muskelödemen nach primärer Tumorresektion. 


\section{Kernaussagen:}

- Primäre aggressive Fibromatosen sind meist faszikulär konfiguriert und weisen eine inhomogene Kontrastmittelaufnahme auf

- Rezidivierende aggressive Fibromatosen sind in der Regel ebenfalls faszikulär konfiguriert und zeigen eine inhomogene oder homogene Kontrastmittelaufnahme

- Patienten innerhalb der ersten 9 postoperativen Monate und bis 25 Jahre weisen ein signifikant erhöhtes Risiko für Rezidive auf

- Muskelödeme nach Resektion einer primären aggressiven Fibromatose sind assoziiert mit einem signifikant höheren Risiko für Rezidive

\section{ABSTRACT}

Purpose To analyze the appearance of primary and recurrent aggressive fibromatosis (AF) on MRI with a focus on configuration and to determine potential risk factors for recurrences detected on MRI follow-up scans.

Methods From 79 consecutive patients with histologically proven diagnosis of $\mathrm{AF}, 39$ patients underwent a minimum of four 1.5 T MRI follow-up scans after resection of primary AF between 2008 and 2018. The primary and recurrent tumors were radiographically examined for configuration, limitation and extent on MRI. Epidemiological data and loco-regional subcutaneous edema, muscle edema and post-operative seroma were included.

Results The mean age of the patients was $39 \pm 2.6$ years. Primary and recurrent AF most often occurred in the thigh. The main appearance of primary AF was significantly most often fascicular ( $p=0.001-0.01$ ) with heterogeneous and marked contrast enhancement. $21 \%(n=8)$ of the patients developed recurrences of AF. A fascicular configuration with homogeneous/heterogeneous contrast enhancement was the main appearance of recurrent $\mathrm{AF}$, but recurrent $\mathrm{AF}$ appeared nodular, polycyclic, ovoid or streaky/flat as well. Recurrent AF significantly most often occurred within the first
9 months after primary tumor resection ( $p=0.009$ ), especially in patients up to 25 years of age $(\mathrm{RR}=6.1 ; 95 \% \mathrm{Cl}: 1.8-20.9$; $p=0.004)$. The cases of recurrent $A F$ were altogether significantly smaller than the primary tumors $(p=0.001)$. Posttreatment subcutaneous and muscle edema were present in $77 \%$ and $56 \%$, respectively. Patients with muscle edema after primary tumor resection had a significantly higher risk for AF recurrences (relative risk ratio $(R R)=1.8 ; 95 \% \mathrm{Cl}$ : 1.16-2.8; $\mathrm{p}=0.0096$ ). There was no significant difference detected in patients with complete or incomplete resection of the primary tumor.

Conclusion Primary and recurrent aggressive fibromatosis has a mostly fascicular configuration, but may appear ovoid, nodular, streaky/flat or polycyclic as well. High risks for tumor recurrences are detected for patients up to 25 years of age, patients within the first 9 post-operative months and patients with muscle edema after primary tumor resection.

\section{Key points:}

- Primary aggressive fibromatosis mostly has a fascicular configuration with heterogeneous contrast enhancement

- Recurrent aggressive fibromatosis usually has a fascicular configuration with heterogeneous/homogeneous contrast enhancement

- Patients within the first 9 post-operative months and up to 25 years of age have a significantly higher risk for recurrences

- Muscle edema after resection of primary aggressive fibromatosis is associated with a significantly higher risk for recurrences

\section{Citation Format}

- Sedaghat S, Surov A, Krohn S et al. Configuration of Primary and Recurrent Aggressive Fibromatosis on ContrastEnhanced MRI with an Evaluation of Potential Risk Factors for Recurrences in MRI Follow-Up. Fortschr Röntgenstr 2020; 192: 448-457

\section{Introduction}

Aggressive fibromatosis (AF), also called desmoid tumor, is defined as a locally aggressive (myo)fibroblastic neoplasm usually arising from deep soft tissues with an infiltrative growth and a tendency to local recurrences, but a lack of metastatic potential [1]. AF mostly affects patients between 16 and 60 years of age with two relative incidence peaks reported in the literature: 6 to 15 years of age, as well as between puberty and the age of 40 $[2,3]$. AF may arise anywhere in the body and is described as multifocal in $10 \%$ of cases $[4,5]$. Furthermore, AF comprises up to $3 \%$ of all soft-tissue tumors [6]. The local recurrence rates of AF range from $15 \%$ to $77 \%$ [6-12]. The most common imaging modalities for $\mathrm{AF}$ are computed tomography (CT) and magnetic resonance (MR) imaging, as well as ultrasonography (US) [4]. For the evaluation of recurrent AF, MR imaging is preferable [13]. In MR imaging
AF mostly presents with a heterogeneous pattern and variable, moderate-to-marked contrast enhancement after infusion of gadolinium-based contrast agent $[4,14,15]$. Nevertheless, studies on the appearance and configuration of aggressive fibromatosis are still lacking, especially in the case of recurrent aggressive fibromatosis. Therefore, the main aim of this study was to analyze the appearance of primary and recurrent aggressive fibromatosis on MRI with a focus on configuration. The second aim was to determine potential risk factors for recurrences detected on MRI follow-up scans, as different variables like age, tumor size and location have been discussed for the determination of prognosis in patients with AF. 


\section{Localization of primary and recurrent AF}

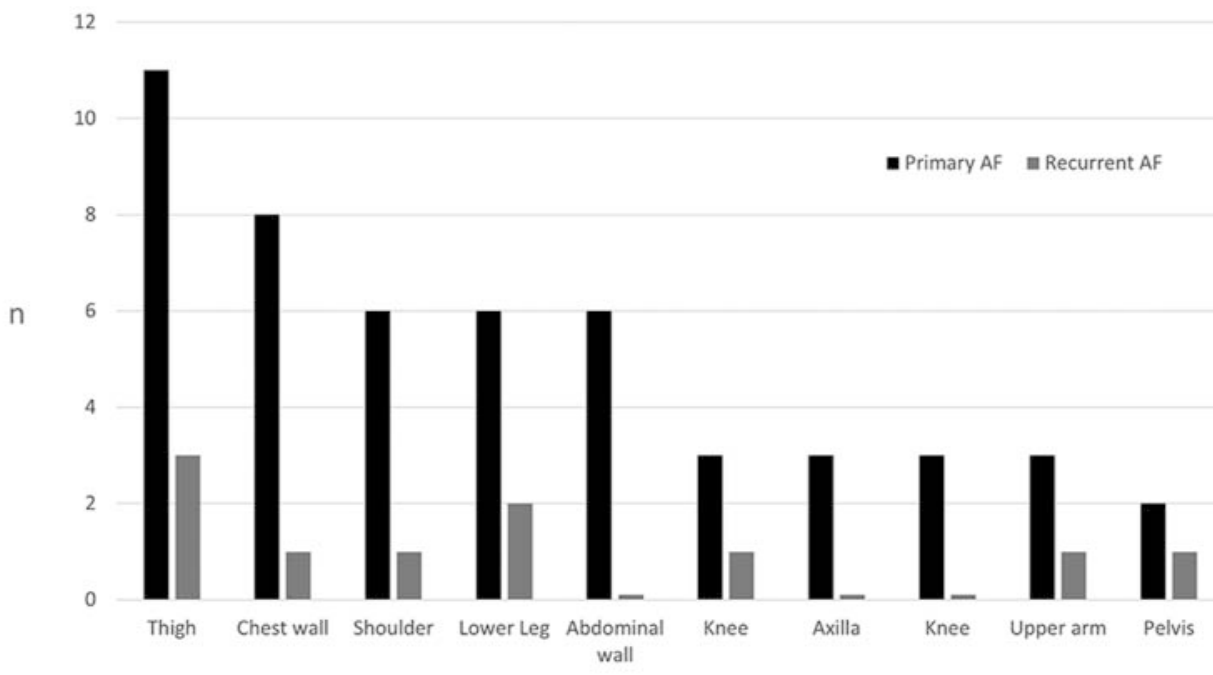

- Fig. 1 Location of primary and recurrent aggressive fibromatosis, shown as number of patients " $\mathrm{n}$ " in the different locations.

- Abb. 1 Lokalisation primärer und rezidivierender aggressiver Fibromatosen, abgebildet als Anzahl von Patienten „ $\mathrm{n}$ “ in unterschiedlichen Lokalisationen.

- Table 1 Configuration, limitation and contrast enhancement of 20 cases of primary aggressive fibromatosis "P" with age of manifestation in years and the mean diameter of the primary tumors in "mm". Statistical significance was determined with $\mathrm{p}<0.05$ being significant.

> Tab. 1 Konfiguration, Begrenzung und Kontrastmittelaufnahme von 20 Fällen primärer aggressiver Fibromatosen „P“ mit Manifestationsalter in Jahren und mittlerem Durchmesser der Primärtumoren in „mm“. Die statistische Signifikanz wurde mit p $<0.05$ bestimmt.

\begin{tabular}{|c|c|c|c|c|c|c|c|c|}
\hline \multirow{2}{*}{$\begin{array}{l}\text { primary } \\
\text { AF (no.) }\end{array}$} & \multicolumn{3}{|c|}{ contrast agent enhancement } & \multicolumn{2}{|c|}{ limitation } & \multirow[t]{2}{*}{ configuration } & \multirow{2}{*}{$\begin{array}{l}\text { age of manifestation } \\
\text { (yrs.) }\end{array}$} & \multirow{2}{*}{$\begin{array}{l}\text { mean diameter } \\
(\mathrm{mm})\end{array}$} \\
\hline & $\begin{array}{l}\text { homo- } \\
\text { geneous }\end{array}$ & $\begin{array}{l}\text { hetero- } \\
\text { geneous }\end{array}$ & intensity & sharply & $\begin{array}{l}\text { infiltra- } \\
\text { tive }\end{array}$ & & & \\
\hline 1 & - & $x$ & +++ & $x$ & $x$ & fascicular & 43 & 50 \\
\hline 2 & - & $x$ & +++ & - & $x$ & fascicular & 36 & 47 \\
\hline 3 & - & $x$ & ++ & $x$ & - & fascicular & 54 & 50 \\
\hline 4 & $x$ & $x$ & +++ & $x$ & $x$ & fascicular & 36 & 83 \\
\hline 5 & - & $x$ & ++ & $x$ & $x$ & fascicular & 26 & 77 \\
\hline 6 & - & $x$ & +++ & - & $x$ & fascicular & 27 & 41 \\
\hline 7 & - & $x$ & ++ & $x$ & $x$ & fascicular & 71 & 50 \\
\hline 8 & $x$ & - & ++ & $x$ & $x$ & fascicular & 58 & 61 \\
\hline 9 & $x$ & $x$ & +++ & - & $x$ & fascicular & 26 & 40 \\
\hline 10 & - & $x$ & +++ & $x$ & $x$ & fascicular & 69 & 53 \\
\hline 11 & $x$ & - & +++ & $x$ & $x$ & fascicular & 28 & 39 \\
\hline 12 & - & $x$ & + & - & $x$ & fascicular & 35 & 71 \\
\hline 13 & $X$ & - & +++ & $x$ & - & ovoid & 24 & 24 \\
\hline 14 & $x$ & - & +++ & $x$ & - & ovoid & 29 & 73 \\
\hline 15 & $x$ & - & +++ & $x$ & - & ovoid & 14 & 15 \\
\hline 16 & - & $x$ & + & $x$ & - & ovoid & 78 & 19 \\
\hline 17 & - & $x$ & +++ & $x$ & $x$ & polycyclic & 16 & 106 \\
\hline
\end{tabular}


- Table 1 (Continuation)

\begin{tabular}{|c|c|c|c|c|c|c|c|c|}
\hline \multirow{2}{*}{$\begin{array}{l}\text { primary } \\
\text { AF (no.) }\end{array}$} & \multicolumn{3}{|c|}{ contrast agent enhancement } & \multicolumn{2}{|c|}{ limitation } & \multirow[t]{2}{*}{ configuration } & \multirow{2}{*}{$\begin{array}{l}\text { age of manifestation } \\
\text { (yrs.) }\end{array}$} & \multirow{2}{*}{$\begin{array}{l}\text { mean diameter } \\
(\mathrm{mm})\end{array}$} \\
\hline & $\begin{array}{l}\text { homo- } \\
\text { geneous }\end{array}$ & $\begin{array}{l}\text { hetero- } \\
\text { geneous }\end{array}$ & intensity & sharply & $\begin{array}{l}\text { infiltra- } \\
\text { tive }\end{array}$ & & & \\
\hline 18 & - & $x$ & + & $x$ & - & polycyclic & 66 & 190 \\
\hline 19 & $x$ & - & ++ & $x$ & $x$ & flat & 46 & 28 \\
\hline 20 & $x$ & - & + & $x$ & - & streaky & 33 & 25 \\
\hline p-value & \multicolumn{2}{|c|}{$\begin{array}{l}\text { fascicular/hetero- } \\
\text { geneous: } 0.01 \text {, } \\
\text { total: } 0.54\end{array}$} & - & \multicolumn{2}{|l|}{0.38} & $\begin{array}{l}\text { fascicular: } 0.001- \\
0.01 \text {, ovoid: } 0.39\end{array}$ & - & - \\
\hline mean/SD & & & & & & & 40.8/SD 19.1 & 57.1/SD 39 \\
\hline
\end{tabular}

\section{Patients and Methods}

\section{Patients}

From 286 patients with soft-tissue sarcoma, 79 consecutive patients with histologically proven diagnosis of extra-abdominal aggressive fibromatosis between 2008 and 2018 were reviewed. Patients with abdominal aggressive fibromatosis as well as patients who underwent examinations other than MRI (18 cases) were excluded. 22 patients were excluded due to insufficient imaging data. 39 patients underwent a minimum of four MRI follow-up scans (equivalent to one year of MRI follow-up) after resection of primary AF at our institution. As general epidemiological data, the age of the patient at primary diagnosis, the location of the primary and recurrent tumors and the recurrence-free MRI follow-up interval were analyzed. The primary and recurrent tumors were radiographically examined for configuration, limitation, extent and contrast enhancement (heterogeneous/homogeneous and intensity) on MRI. The extent was measured as the mean of length, width, height. For the detection of potential risk factors, epidemiological data and loco-regional post-treatment changes of the soft-tissue (subcutaneous and muscle edema, as well as postoperative seroma) were included. Resection status (R0-2) was extracted from the histological reports.

MR imaging was performed with a 1.5 Tesla MRI system (MAGNETOM Symphony, Siemens Healthineers). The MRI protocol was performed with the following sequences: axial T2-weighted (TE: 64-114 ms, TR: $3010-5840 \mathrm{~ms}$, FOV: $22-44 \mathrm{~cm}$, SD: 5-6 mm), axial T1-weighted (TE: 10-14 ms, TR: 587-868 ms, FOV: 22-44 cm, SD: 5-6 mm), axial proton density-weighted (PDw) (TE: 26-36 ms, TR: 2740-4610 ms, FOV: $22-40 \mathrm{~cm}$, SD: 5-6 mm), coronal Turbo-Inversion Recovery-Magnitude (TIRM) (TE: 68-77 ms, TR: 4410-6980 ms, FOV: $37-45 \mathrm{~cm}$, SD: 4-6 mm), axial (10-12 ms, TR: 645-865 ms, FOV: 22-44 cm, SD: 5-6 mm), coronal (TE: 10-13 ms, TR: 533-1440 ms, FOV: $37-45 \mathrm{~cm}$, SD: 4-6 mm) and sagittal (TE: 10-13 ms, TR: 577$866 \mathrm{~ms}$, FOV: 22-37 cm, SD: 5-10 mm) T1-weighted after application of IV contrast agent.

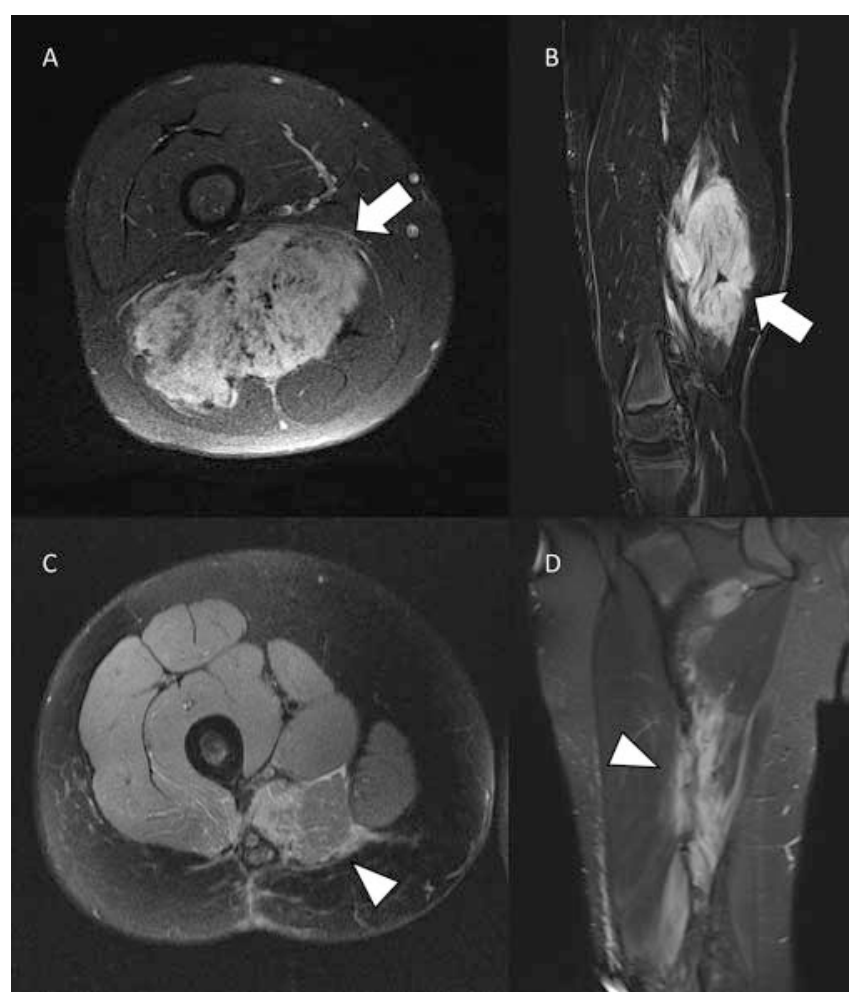

- Fig. 2 1.5 T MRI (T1w FS after application IV gadolinium A, B and PDw FS C, D) of the thigh of a 56-year-old patient, showing a preoperative fascicular configuration of primary AF with heterogeneous and marked contrast enhancement (white arrow). Postoperative muscle edema after tumor resection is present (white arrowhead).

- Abb.2 1.5 T MRT (T1w FS nach Kontrastmittelgabe A, B und PDw FS C, D) des Oberschenkels eines 56 Jahre alten Patienten, welches präoperativ eine faszikulär konfigurierte primäre aggressive Fibromatose mit inhomogener und deutlicher Kontrastmittelaufnahme zeigt (weißer Pfeil). Zudem zeigt sich ein postoperatives Muskelödem (weiße Pfeilspitze).

Two dedicated sarcoma radiologists, with 18 and 9 years of sarcoma diagnostics experience, respectively, reviewed each MRI with findings reached by consensus. The reviewers were blinded 


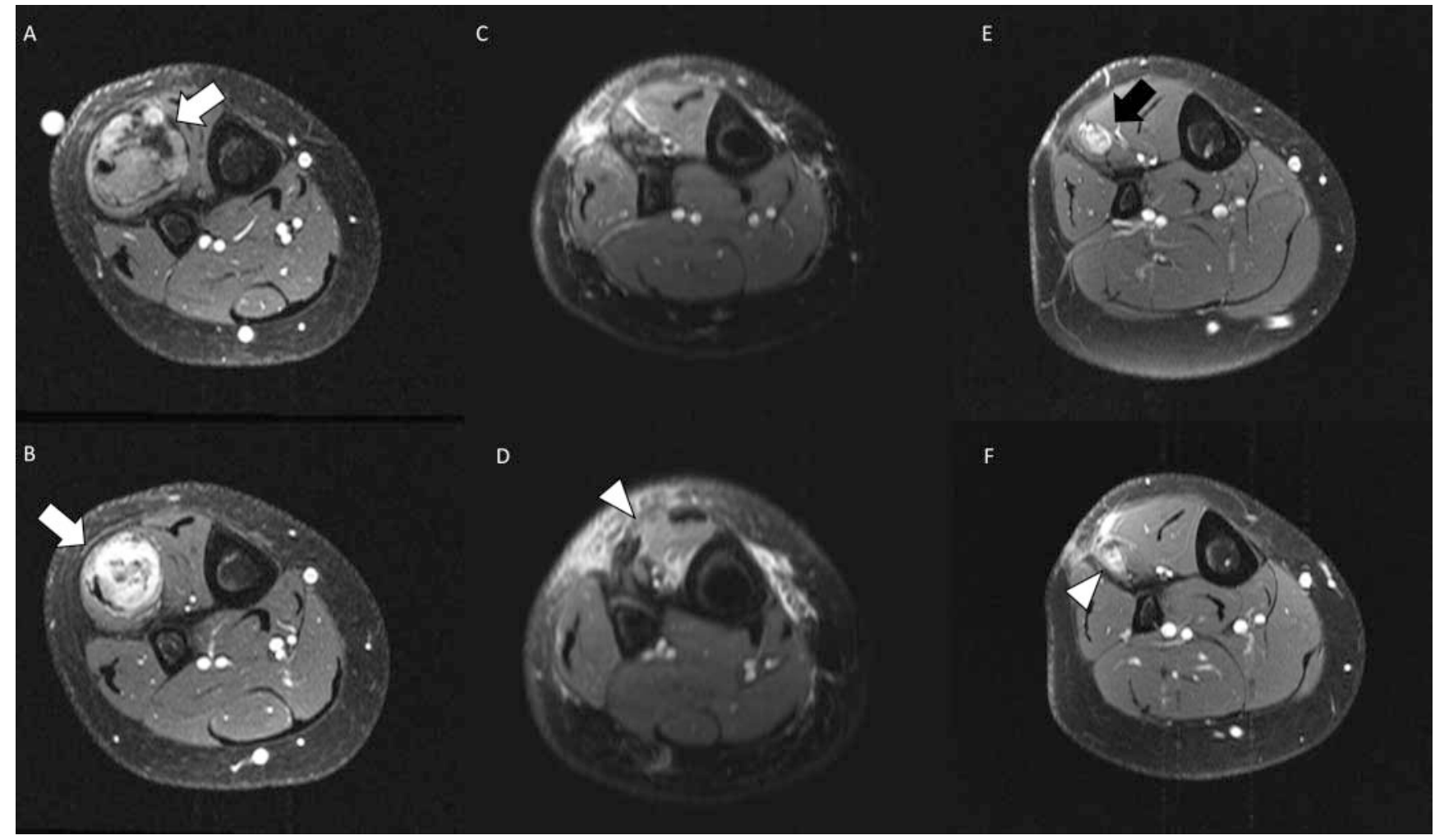

- Fig. 3 1.5 T MRI (T1w FS after application IV gadolinium A, B, E, F and PDw FS C, D) of the lower leg of a 14-year-old patient. Primary tumor (white arrow) with a preoperative A, B fascicular configuration is shown. Within the first 3 post-operative months $\mathbf{C}$, D, the patient developed muscle edema (white arrowhead). 6 months after primary tumor resection, the patient presented with ovoid and sharply limited recurrent AF, as well as homogeneous and marked contrast enhancement (black arrow).

- Abb.3 1.5 T MRT (T1w FS nach Kontrastmittelgabe A, B, E, F und PDw FS C, D) des Unterschenkels eines 14 Jahre alten Patienten. Der Primärtumor (weißer Pfeil) weist präoperativ A, B eine faszikuläre Konfiguration auf. Innerhalb der ersten 3 postoperativen Monate C, D entwickelte der Patient ein Muskelödem (weiße Pfeilspitze). 6 Monate nach primärer Tumorresektion zeigte der Patient ein ovalär und scharf begrenztes Rezidiv einer aggressiven Fibromatose mit zudem homogener und deutlicher Kontrastmittelaufnahme (schwarzer Pfeil).

to clinical and patient data and were not involved in the inclusion and exclusion process.

\section{Statistical data}

If not indicated otherwise, data are given as median values with range (minimum to maximum) or mean with standard deviation (SD). Parametric and nonparametric tests to compare group values (X2-test, Mann-Whitney U-test, ANOVA) were performed as indicated. Furthermore, the relative risk ratios (RR) for the determination of relative risks were analyzed. The statistical significance for all tests was set at a level of $p<0.05$. Statistical analysis was done using the IBM-SPSS version 22.0 software package (IBM, Armonk, NY, USA).

\section{Ethics approval}

The study was conducted in accordance with and was approved by the responsible ethics committee.

\section{Results}

The mean age of the patients was 39 years (SD: 2.6; Min.: 14, Max.: 78). The diagnosis of AF was seen slightly more often in women $(n=43)$ than in men $(n=36)$. From 65 patients we gained information about the location of primary AF. With 11 of 65 cases, the thigh was the most common location for primary AF, followed by the chest wall with 8 cases. Primary AF occurred significantly most often in the thigh $(p<0.05)$. Recurrent AF occurred most often in the thigh as well ( $\vee$ Fig. 1).

The main configuration of primary AF was significantly most often fascicular ( $p=0.001-0.01$, > Table 1, > Fig. 2). However, in patients up to 30 years of age, primary AF often showed an ovoid configuration with homogeneous and marked contrast agent enhancement ( $\vee$ Fig. 3 ) as well. In $21 \%(n=8)$ we found recurrences of AF. A fascicular configuration with homogenous/heterogeneous contrast enhancement was the main configuration of recurrent $A F$ ( $\triangleright$ Fig. 4), but recurrent $A F$ also appeared multifocal nodular or flat, polycyclic, fascicular, ovoid or streaky/flat ( $\triangleright$ Fig.3-5; $>$ Table 2). Recurrent AF significantly most often occurred within the first 9 months after primary tumor resection $(p=0.009)$, especially in patients up to 25 years of age ( $\nabla$ Fig. 6 ). 


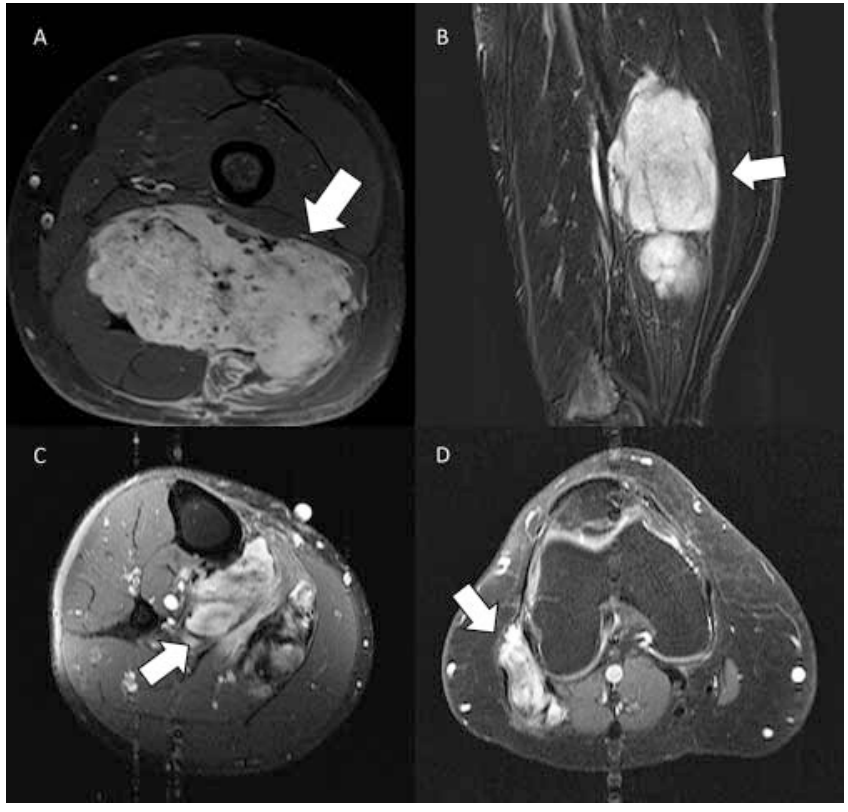

- Fig.4 1.5 T MRI (T1w FS after application IV gadolinium) of the thigh $\mathbf{A}, \mathbf{B}$, the lower leg $\mathbf{C}$ and knee $\mathbf{D}$ of three different patients. The contrast-enhanced MR images show recurrent tumors with a fascicular configuration (white arrow) with heterogeneous $\mathbf{A}-\mathbf{C}$ and homogeneous $\mathbf{D}$ contrast enhancement.

- Abb.4 1.5 T MRT (T1w FS nach Kontrastmittelgabe) des Oberschenkels A, B, des Unterschenkels $\mathbf{C}$ und des Knies $\mathbf{D}$ von drei unterschiedlichen Patienten. Die kontrastmittelgestützten MRTAbbildungen zeigen Rezidivtumoren mit faszikulärer Konfiguration (weißer Pfeil) sowie inhomogener A-C und homogener D Kontrastmittelaufnahme.

The relative risk ratio ( $R R)$ for recurrences in patients up to 25 years of age was 6.1 (95\% Cl: 1.8-20.9, $\mathrm{p}=0.004)$. The combined relative risk ratio (RR) for recurrences within the first 9 months and in patients up to 25 years of age was $7.1(95 \% \mathrm{Cl}$ : 2.1-23.7, $p=0.0015)$.

The mean diameter of primary AF was $57.1 \mathrm{~mm}$ (Min.: 15, Max.: 190, SD 39). The recurrent tumors were altogether significantly smaller with a mean diameter of $30.2 \mathrm{~mm}$ (SD: $25.5 \mathrm{~mm}$; $\mathrm{p}=0.001$; Fig. 7). The most common post-treatment changes in soft-tissue were subcutaneous and muscle edema (77\% and $56 \%$, respectively). Patients with muscle edema after primary tumor resection had a significantly higher risk for AF recurrences (RR: 1.8; $95 \%$ Cl: 1.16-2.8; $\mathrm{p}=0.0096$; Table 3). 10 patients underwent a histologically incomplete resection (R1 and R2) and 22 patients a complete R0-resection of the primary tumor. There was no significant difference detected in patients with complete or incomplete resection of the primary tumor (RR: 1.1; $95 \% \mathrm{Cl}$ : $0.3-3.8 ; p=0.941)$.

\section{Discussion}

In this study we mainly analyzed the configuration of primary and recurrent extra-abdominal AF on MRI. Previous studies on AF imaging mainly addressed signal characteristics of AF rather than the appearance of the tumors. Furthermore, primary AF is the main subject of previous studies. In our study we both examined primary and recurrent tumors with a focus on the configuration on MRI. Additionally, we tried to analyze potential indications of recurrent $A F$ on follow-up MRI scans. AF is described as a locally aggressive fibroblastic neoplasm with no potential for metastasis, but a high tendency to recur after surgical resection [4]. In our study the mean age of the patients is 39 years, ranging from 16 to 78 years at the time of primary diagnosis, which mainly coincides with previous data [3]. Furthermore, extra-abdominal AF is reported to occur slightly more often in women than in men [14].

Previous studies show that primary AF of the lower extremities is very rare [16]. However, it should be mentioned that there is no common data about the frequency of AF locations. In our study primary AF of the lower leg is a very common diagnosis, for example.

MRI is considered the best imaging modality in the diagnosis and staging of primary and recurrent AF [17]. Many previous studies have been concerned with the T1- and T2-signal characteristics of $A F$, while only a few studies have investigated the appearance of AF $[4,13,18,19]$. Nevertheless, conventional MR sequences with T1- and T2-weighted imaging have limited value [20]. Therefore, the application of contrast agent is often necessary. In our study all of our patients underwent native and contrast-enhanced MRI. According to Lee JC et al., the most common findings of AF on MRI are an ovoid or infiltrative lesion that is lobulated or irregular in outline and crosses fascial and shows strong enhancement after IV gadolinium administration [19]. Furthermore, the MR imaging appearance of AF is mostly described with a heterogeneous pattern $[4,18]$. In our study the main shape of the primary tumors is fascicular with 12 of 20 cases (60\%), but can also be ovoid as seen in three cases in patients under 30 years or even polycyclic as seen in 2 cases. AF can furthermore show homogeneous or heterogeneous, in most cases strong, in a few cases weak contrast enhancement and can be infiltrative or sharply limited. Previous publications describe AF as appearing in different shapes [19, 21, 22]. In our study this applies to recurrent AF, which shows no common appearance in MRI sequences, even though a fascicular configuration is most common. Based on our experience, this fact makes a distinction from post-therapeutic changes often very difficult. While AF with a fascicular configuration is simple to distinguish from post-treatment changes, a recurrent tumor with an ovoid, nodular or streaky configuration is often difficult to differentiate from post-treatment changes. Additionally, there is no comparable data about the appearance of recurrent AF. This uncertainty may lead to false-positive suspicions and consecutively to unnecessary biopsies of the postoperative tissue [23]. The literature mostly reports recurrence rates for AF of fewer than $50 \%$, ranging from $11 \%$ to $64 \%[1,9,14,24]$. Mueller et al. describe an average recurrence rate of $33 \%$ after complete gross resection of the primary tumor [24]. In our study the recurrence rate coincides with previous data $(21 \%$ after primary tumor resection). However, the specificity of MRI for the detection of recurrent soft-tissue tumors has been previously reported to be moderate (52\%) [23]. On the other hand, Park C. et al. describe a high sensitivity and specificity of MRI for the detection of recurrent soft-tissue tumors [25]. Different variables like age, tumor size 


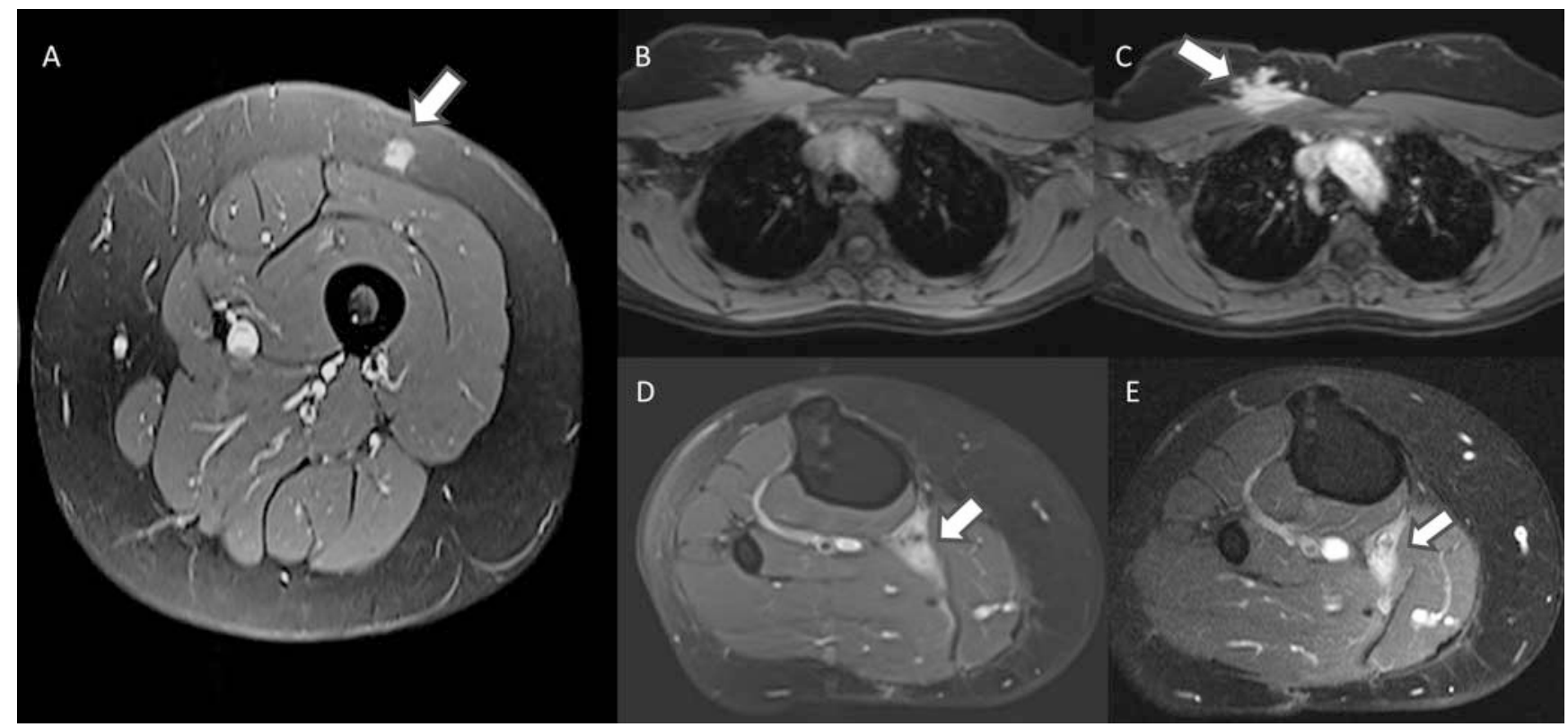

- Fig. 5 1.5 T MRI (T1w FS after application IV gadolinium) of three different locations: Nodular and homogeneous recurrent AF in the anterior subcutaneous tissue of the thigh $\mathbf{A}$. Streaky/flat and homogeneous recurrent AF in the right chest wall B, C. Marked contrast enhancement after IV application of contrast agent $\mathbf{C}$ with extension to the subcutaneous tissue. Streaky and homogeneous contrast-enhancing recurrent AF in the lower leg (white arrow), which can easily be confounded by post-treatment muscle edema $\mathbf{D}, \mathbf{E}$.

- Abb.5 1.5 T MRT (T1w FS nach Kontrastmittelgabe) von drei unterschiedlichen Lokalisationen: Nodulär und homogen konfigurierter Rezidivtumor im anterioren subkutanen Weichgewebe des Oberschenkels A. Streifiger/flächiger und homogener Rezidivtumor in der rechten Brustwand B, C. Deutliche Kontastmittelanreicherung nach IV-Gabe von Kontrastmittel C mit Ausläufern in das Subkutangewebe. Streifig konfigurierter und homogen Kontrastmittel aufnehmender Rezidivtumor im Unterschenkel (weißer Pfeil), der leicht mit posttherapeutischem Muskelödem verwechselt werden kann D, E.

- Table 2 Configuration, limitation and contrast enhancement of 8 cases of recurrent aggressive fibromatosis "R" with age of manifestation in years and the mean diameter of the primary tumors in " $\mathrm{mm}$ ". Statistical significance was determined with $\mathrm{p}<0.05$ being significant.

- Tab.2 Konfiguration, Begrenzung und Kontrastmittelaufnahme von 8 Fällen rezidivierender aggressiver Fibromatosen „R“ mit Manifestationsalter in Jahren und mittlerem Durchmesser der Primärtumoren in „mm“. Statistische Signifikanz wurde als p<0.05 bestimmt.

\begin{tabular}{|c|c|c|c|c|c|c|c|c|}
\hline \multirow{2}{*}{$\begin{array}{l}\text { recurrent } \\
A F \text { (no.) } \\
R=\text { recur- } \\
\text { rence }\end{array}$} & \multicolumn{3}{|c|}{ contrast enhancement } & \multicolumn{2}{|c|}{ limitation } & \multirow[t]{2}{*}{ configuration } & \multirow{2}{*}{$\begin{array}{l}\text { age of manifestation } \\
\text { (yrs.) }\end{array}$} & \multirow{2}{*}{$\begin{array}{l}\text { mean diameter } \\
(\mathrm{mm})\end{array}$} \\
\hline & $\begin{array}{l}\text { homo- } \\
\text { geneous }\end{array}$ & $\begin{array}{l}\text { hetero- } \\
\text { geneous }\end{array}$ & $\begin{array}{l}\text { inten- } \\
\text { sity }\end{array}$ & sharply & $\begin{array}{l}\text { infiltra- } \\
\text { tive }\end{array}$ & & & \\
\hline R1 & $x$ & - & +++ & - & $x$ & $\begin{array}{l}\text { multifocal, not uniform } \\
\text { (flat, nodular) }\end{array}$ & 16 & 23 \\
\hline R2 & - & $x$ & ++ & $x$ & $x$ & polycyclic & 43 & 40,19 \\
\hline R3 & $x$ & - & +++ & $x$ & - & ovoid & 14 & 15 \\
\hline R4.1 & $x$ & - & +++ & $x$ & - & streaky/flat & 18 & 15 \\
\hline R4.2 & - & $x$ & +++ & - & $x$ & streaky/flat & 18 & 20 \\
\hline R5 & $x$ & - & +++ & $x$ & $x$ & fascicular & 21 & 39 \\
\hline R6 & $x$ & - & +++ & $x$ & $x$ & fascicular & 24 & 47 \\
\hline R7 & - & $x$ & +++ & $x$ & $x$ & fascicular & 32 & 16 \\
\hline R8.1 & - & $x$ & +++ & $x$ & $x$ & fascicular & 28 & 15 \\
\hline R8.2 & - & $x$ & +++ & $x$ & $x$ & fascicular & 28 & 20 \\
\hline p-value & - & & & - & & fascicular: 0.06 & & \\
\hline mean/SD & & & & & & & 24.5/SD 9.6 & 26/SD 12.5 \\
\hline
\end{tabular}




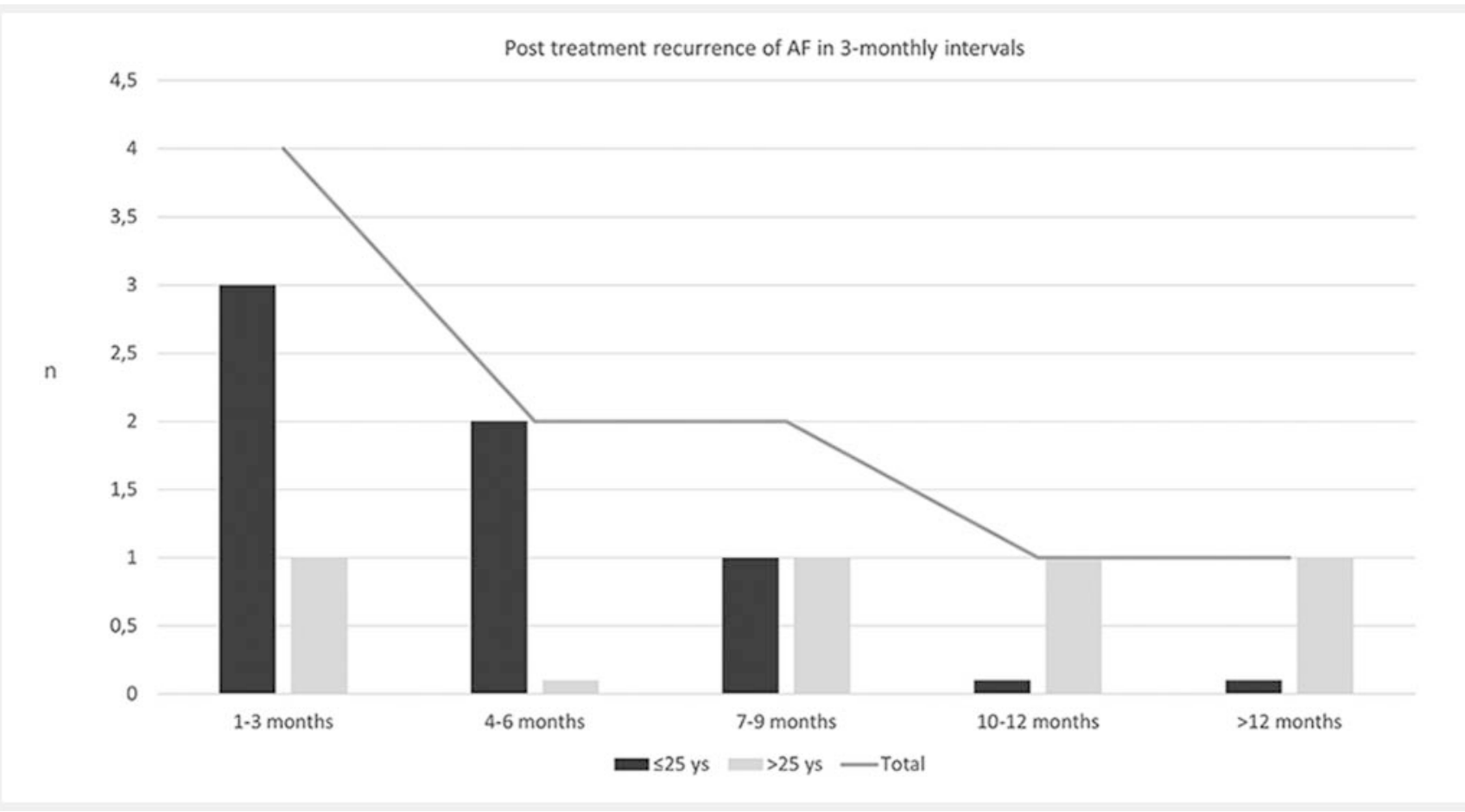

D Fig. 6 Post-treatment occurrence of recurrent AF in 3-month intervals, shown in months and number of recurrences " $n$ " in total, as well as in patients up to 25 and over 25 years of age.

- Abb. 6 Posttherapeutisches Auftreten rezidivierender aggressiver Fibromatosen in 3-Monatsintervallen, abgebildet in Monaten und Anzahl der Rezidive „n“, sowohl insgesamt, als auch für Patienten bis und über 25 Jahren.

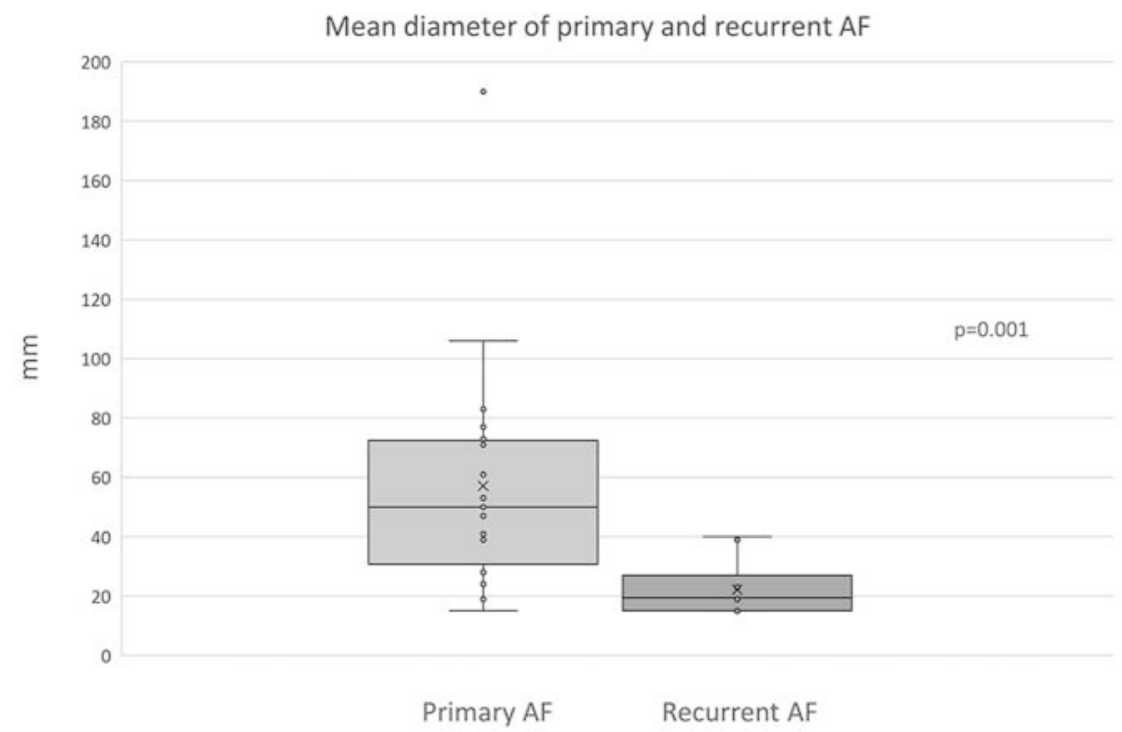

- Fig. 7 Comparison of mean diameters of primary and recurrent aggressive fibromatosis. The data is shown in median, $25 \% \mathrm{KI}, 75 \% \mathrm{KI}$, minimum and maximum range. Statistical significance was determined with $\mathrm{p}<0.05$ being significant.

- Abb.7 Vergleich der mittleren Durchmesser primärer und rezidivierender aggressiver Fibromatosen. Die Daten sind abgebildet in Median, $25 \% \mathrm{KI}, 75 \% \mathrm{KI}$, minimale und and maximale Ausdehnung. Die statistische Signifikanz wurde mit $\mathrm{p}<0.05$ bestimmt. 
- Table 3 Total post-therapeutic changes, in patients with and without recurrent aggressive fibromatosis. The data is shown as the number of patients " $n$ " and percentage "\%". Relative risk ratios (RR) were determined for patients with and without recurrences. Statistical significance was determined with $\mathrm{p}<0.05$ being significant.

- Tab.3 Posttherapeutische Veränderungen bei Patienten mit und ohne rezidivierende aggressive Fibromatosen. Die Daten sind abgebildet als Anzahl von Patienten „n“ und in Prozent „\%“. Das relative Risiko (RR) wurde bestimmt für Patienten mit und ohne Rezidive. Die statistische Signifikanz wurde mit $\mathrm{p}<0.05$ bestimmt.

\begin{tabular}{|l|l|l|l|l|}
\hline post-treatment changes & $\begin{array}{l}\text { total } \\
\text { (39 patients) }\end{array}$ & $\begin{array}{l}\text { patients with recurrences } \\
\mathbf{( 8 ~ p a t i e n t s )}\end{array}$ & $\begin{array}{l}\text { patients without } \\
\text { recurrences } \\
\text { (31 patients) }\end{array}$ & relative risk ratio (RR); p-value \\
\hline & $\mathbf{n} / \%$ & n/\% & \\
\hline & total (n/\%) & $24 / 77$ & $-; 0.77$ \\
\hline subcutaneous edema & $30 / 77$ & $6 / 75$ & $15 / 48$ & RR: $1.8 ; 95 \% \mathrm{Cl}: 1.16-2.8 ; \mathrm{P}=0.0096$ \\
\hline muscle edema & $22 / 56$ & $7 / 88$ & $5 / 16$ & $-; 0.71$ \\
\hline postoperative seroma & $6 / 15$ & $1 / 13$ & & \\
\hline
\end{tabular}

and location are discussed for the determination of prognosis. In our study recurrent AF occurs significantly most often within the first 9 months after primary tumor resection, especially in patients up to 25 years of age. Patients fitting these criteria should be carefully screened, because they have a 6 to 7 times higher risk for tumor recurrences. Accordingly, some authors report that a younger age is associated with a higher risk of recurrent AF [26, 27]. A reason for this phenomenon could be the presence of very small remnants of tumor cells after resection, which favors the occurrence of recurrent AF on MRI within the first months after resection. The type of resection (R0-2) does not play a significant role in our study, which coincides with previous data that denies any correlation between negative margin status and outcome [28]. Nevertheless, many authors state that a negative margin (R0) has a significant impact on recurrences [26, 29].

The mean sizes of the recurrent tumors are significantly smaller than the primary tumors. A comparable study is unfortunately not available. In the routine setting recurrences of AF are detected in stages, where they are still small.

In addition, MRI plays an important role in the post-treatment evaluation of soft-tissue changes as well. Differentiation between post-therapeutic soft tissue changes and tumor recurrence is often problematic [30], since in our experience post-treatment subcutaneous tissue and muscle changes can mimic recurrences of AF. Furthermore, there is no sufficient data about post-treatment changes after resection of primary aggressive fibromatosis or other soft-tissue sarcoma. The overall most common posttreatment changes are muscle and subcutaneous tissue edema, as AF is a locally aggressive (myo)fibroblastic neoplasm [1]. Anyway, we detected a significantly higher rate of muscle edema prior to the occurrence of recurrences. The risk for tumor recurrences is approximately two times higher in these patients than in patients without muscle edema. Either muscle edema favors the occurrence of recurrences and is a real risk factor for $A F$ recurrences or muscle edema is a side effect of residual tumor. This question cannot be clarified in this study and further studies are needed to examine this possible trend.
Our study has some limitations. The main limitations are the retrospective design and the single-center approach of the present study. Patients with a diagnosis of AF are very rare. Furthermore, most patients with the diagnosis of AF are transferred to sarcoma centers, when the diagnosis is already clear. This additionally minimizes the already small amount of AF imaging data. Therefore, the inclusion of sufficient patient data in a prospective study would be time-consuming. However, a multicenter study approach would bring a real benefit to this type of study. Even though a sarcoma center is affiliated with our institution, we cannot achieve such high numbers of patients as we could with a multicenter study. A multicenter approach could bring an enormous advantage, especially in the detection of risk factors for $A F$ recurrences or with respect to evidence of the appearance of $A F$ recurrences. Therefore, further studies on AF should be multicenter.

\section{Conclusion}

Most cases of primary and recurrent aggressive fibromatosis have a fascicular configuration, but may also appear ovoid, nodular, streaky/flat or polycyclic. There is a significantly higher risk for recurrences in patients up to 25 years of age, in patients within the first 9 months after primary tumor resection and in patients with muscle edema after primary tumor resection. Further studies are needed, preferably multicentric, to investigate the appearance of $\mathrm{AF}$ recurrences and the role of post-treatment muscle edema in the occurrence of AF recurrences.

\section{Conflict of Interest}

The authors declare that they have no conflict of interest. 


\section{References}

[1] Wirth L, Klein A, Baur-Melnyk A et al. Desmoid Tumours of the extremity and trunk. A retrospective study of 44 patients. BMC musculoskeletal disorders 2018; 19: 2

[2] Eastley N, McCulloch T, Esler C et al. Extra-abdominal desmoid fibromatosis: a review of management, current guidance and unanswered questions. European Journal of Surgical Oncology (EJSO) 2016; 42: 1071-1083

[3] Meazza C, Bisogno G, Gronchi A et al. Aggressive fibromatosis in children and adolescents: the Italian experience. Cancer: Interdisciplinary International Journal of the American Cancer Society 2010; 116: 233-240

[4] Braschi-Amirfarzan M, Keraliya AR, Krajewski KM et al. Role of imaging in management of desmoid-type fibromatosis: a primer for radiologists. Radiographics 2016; 36: 767-782

[5] Wagstaff MJD, Raurell A, Perks AGB. Multicentric extra-abdominal desmoid tumours. British journal of plastic surgery 2004; 57: 362-365

[6] Dalén BM, Bergh P, Gunterberg B. Desmoid tumors A clinical review of 30 patients with more than 20 years' follow-up. Acta Orthopaedica Scandinavica 2003; 74: 455-459

[7] Goy BW, Lee SP, Eilber $F$ et al. The role of adjuvant radiotherapy in the treatment of resectable desmoid tumors. International journal of radiation oncology, biology, physics 1997; 39: 659-665

[8] Kamali F, Wang WL, Guadagnolo BA et al. MRI may be used as a prognostic indicator in patients with extra-abdominal desmoid tumours. The British journal of radiology 2016; 89: 20150308

[9] Merchant NB, Lewis J], Woodruff JM et al. Extremity and trunk desmoid tumors: a multifactorial analysis of outcome. Cancer: Interdisciplinary International Journal of the American Cancer Society 1999; 86: 20452052

[10] Pritchard DJ, Nascimento AG, Petersen IA. Local control of extraabdominal desmoid tumors. JBJS 1996; 78: 848-854

[11] Rock MG, Pritchard DJ, Reiman HM et al. Extra-abdominal desmoid tumors. JBJS 1984; 66: 1369-1374

[12] Sørensen A, Keller J, Nielsen OS et al. Treatment of aggressive fibromatosis: a retrospective study of 72 patients followed for 1-27 years. Acta Orthopaedica Scandinavica 2002; 73: 213-219

[13] Murphey MD, Ruble CM, Tyszko SM et al. Musculoskeletal fibromatoses: radiologic-pathologic correlation. Radiographics 2009; 29: 2143-2183

[14] Mankin HJ, Hornicek FJ, Springfield DS. Extra-abdominal desmoid tumors: A report of 234 cases. Journal of surgical oncology 2010; 102: 380-384

[15] Vandevenne JE, de Am S, de Beuckeleer L et al. New concepts in understanding evolution of desmoid tumors: MR imaging of 30 lesions. European radiology 1997; 7: 1013-1019
[16] Ali Kaygin M, Dag O, Erkut B et al. Extra-abdominal fibromatosis (desmoid tumor): a rare tumor of the lower extremity arising from the popliteal fossa. Case reports in vascular medicine 2011; 2011: 1-3

[17] Pakos EE, Tsekeris PG, Goussia AC. Desmoid tumours of the extremities and trunk: a review of the literature. International orthopaedics 2005; 29: 210-213

[18] Dinauer PA, Brixey C], Moncur JT et al. Pathologic and MR imaging features of benign fibrous soft-tissue tumors in adults. Radiographics 2007; 27: $173-187$

[19] Lee JC, Thomas JM, Phillips S et al. Aggressive fibromatosis: MRI features with pathologic correlation. American Journal of Roentgenology 2006; 186: 247-254

[20] Vanel D, Shapeero LG, de Baere T et al. MR imaging in the follow-up of malignant and aggressive soft-tissue tumors: results of 511 examinations. Radiology 1994; 190: 263-268

[21] Robbin MR, Murphey MD, Temple HT et al. Imaging of musculoskeletal fibromatosis. Radiographics 2001; 21: 585-600

[22] Feld R, Burk DL Jr, McCue $P$ et al. MRI of aggressive fibromatosis: frequent appearance of high signal intensity on T2-weighted images. Magnetic resonance imaging 1990; 8: 583-588

[23] Del Grande F, Subhawong T, Weber K et al. Detection of soft-tissue sarcoma recurrence: added value of functional MR imaging techniques at 3.0 T. Radiology 2014; 271: 499-511

[24] Mueller C, Croner R, Klein P et al. Primary and recurrent sporadic desmoids: prognostic factors influencing recurrence-free survival after complete gross resection. International Journal of Surgery 2016; 31: 6370

[25] Park SY, Chung HW, Chae SY et al. Comparison of MRI and PET-CT in detecting the loco-regional recurrence of soft tissue sarcomas during surveillance. Skeletal radiology 2016; 45: 1375-1384

[26] He XD, Zhang YB, Wang L et al. Prognostic factors for the recurrence of sporadic desmoid-type fibromatosis after macroscopically complete resection: analysis of 114 patients at a single institution. European Journal of Surgical Oncology (EJSO) 2015; 41: 1013-1019

[27] Peng PD, Hyder O, Mavros MN et al. Management and recurrence patterns of desmoids tumors: a multi-institutional analysis of 211 patients. Annals of surgical oncology 2012; 19: 4036-4042

[28] Salas S, Dufresne A, Bui B et al. Prognostic factors influencing progression-free survival determined from a series of sporadic desmoid tumors: a wait-and-see policy according to tumor presentation. J Clin Oncol 2011; 29: 3553-3558

[29] Mullen JT, DeLaney TF, Kobayashi WK et al. Desmoid tumor: analysis of prognostic factors and outcomes in a surgical series. Annals of surgical oncology 2012; 19: 4028-4035

[30] James SL], Davies AM. Post-operative imaging of soft tissue sarcomas. Cancer Imaging 2008; 8: 8 